\begin{tabular}{|c|c|c|}
\hline IDUNAS & $\begin{array}{l}\text { NATURAL \& APPLIED SCIENCES } \\
\text { JOURNAL }\end{array}$ & $\begin{array}{c}2019 \\
\text { Vol. } 2 \\
\text { No. } 2 \\
\text { (38-50) }\end{array}$ \\
\hline
\end{tabular}

\title{
Synthesis, Characterization, Antimalarial and Antimicrobial activities of Mixed Ibuprofen-Pyrimethamine M(II) Complexes [M = Cd, Co, Zn, Mn]
}

\author{
Research Article \\ Mercy O. Bamigboye1* (D), Ikechukwu P. Ejidike2 \\ I Department of Industrial Chemistry, Faculty of Physical Sciences, University of Ilorin, P.M.B. 1515, Ilorin, Kwara State, Nigeria \\ ${ }_{2}$ Department of Chemical Sciences, Faculty of Science and Science Education, Anchor University, P.M.B. O01, Ipaja, Lagos, Nigeria \\ Author E-mails: \\ obaleye.mo@unilorin.edu.ng \\ iejidike@aul.edu.ng \\ *Correspondence to: BAMIGBOYE, M.O., Department of Industrial Chemistry, Faculty of Physical \\ Sciences, University of Ilorin, P.M.B. 1515, Ilorin, Kwara State, Nigeria, EJIDIKE, I.P., Department of \\ Chemical Sciences, Faculty of Science and Science Education, Anchor University, P.M.B. 001, Ipaja, \\ Lagos, Nigeria \\ DOI: 10.38061/idunas.629389
}

Received: October 04, 2019; Accepted: December 31, 2019

\section{Abstract}

Mixed complexes of Ibuprofen-Pyrimethamine were synthesized using $\mathrm{Cd}(\mathrm{II}) \mathrm{Co}(\mathrm{II}), \mathrm{Zn}(\mathrm{II})$, and $\mathrm{Mn}$ (II). The mixed complexes were characterized based on some physicochemical and spectroscopic techniques such as infrared, elemental analysis, conductivity measurements, and magnetic moment. Based on the results obtained, the complexes were formulated as $\left[\mathrm{M}\left(\mathrm{L}_{1}\right)\left(\mathrm{L}_{2}\right)\right] \mathrm{Cl}_{2}$, where $\mathrm{M}=$ metal ion, $\mathrm{L}_{1}=$ Pyrimethamine, L2 = Ibuprofen). The complexes were found to be non-electrolytes. The ligands act as bidentate towards the central metal ions with deprotonation occurring at the carboxylic group. The complexes were also analyzed by conductometric titration. Antimicrobial screening against the selected organisms: Escherichia coli, Pseudomonas aeruginosa, Staphylococcus aureus, Bacillus substilis, Bacillus megaterium and Serratia marcescens for the complexes alongside the free ligands were investigated. The antimalarial study was investigated for the compounds against Plasmodium berghei (NK 65 strain). It was observed that the complexes showed significant potentials against the studied organisms.

Keywords: Ibuprofen, Antimicrobial, Pyrimethamine, Metal Complexes, Antimalarial.

\section{INTRODUCTION}

Research towards improving the therapeutic effects of drugs has become the frontiers of numerous inorganic researchers towards synthesizing potent drugs with better therapeutic effects on microorganisms with resistance to previous drugs (Triathi and Aarti, 2015). Metal-drug complexes are of great interest to researchers due to their different medicinal use for the treatment of diseases (Alaghaz et al., 2013). It was discovered recently that some gold complexes had been investigated for the treatment of Rheumatoid arthritis. Some ruthenium compounds have shown antitumor activity due to the protein and DNA binding capacity of the metal ion (Cassells et al., 2018). Many kinds of research have been carried out on the 
combination of some antimalaria drugs which are effective in the treatment of the disease. Mixed Artesunate and Lapdap (Chlorproguanil/dapsone) drugs have been confirmed to be an improvement in the Treatment of malaria through combined therapy and the elimination of the parasites from the body system (Waziri et al., 2018).

A few years back, the formation of mixed antimalarial drug complexes attracted great attention as a result of their interesting molecular structures (Huang et al., 2016), catalytic abilities and especially their potential uses in the area of the biomedical field (Raheem et al., 2014). Chemotherapy is one of the methods used in the treatment of diseases such as cancer. The spread of parasites resistant to some drugs has become a cause for concern to researchers, and the recommendation to use a combination of drugs for full treatment has received wide attention (Enermose et al., 2014). Synthesis of novel metal-drug complexes depends on the capability of the central metal ions to enhance the therapeutic ability of the drug. Hence, some drugs are more effective upon coordination to the central metal ions (Recio Despaigne et al., 2014). Some metal complexes have been reported to be more effective than their parent ligand, such as bleomycin (Li-June, 2003). Many biologically active compounds used as drugs possess enhanced modified pharmacological and toxicological potentials when administered in the form of metal-based compounds (Ibrahim et al., 2015; Babamale et al., 2016). More research has been carried out on the application of antimalaria drug metal complexes which has which are more recognized as a leading candidate for the treatment of different infectious diseases (Padman et al., 2016). The preparation of antimalaria drug metal complexes has led the research into the effect of the coordinated metal ion on the pharmacological properties of the ligand (Ramachandran et al., 2017; Safila and Lailoona, 2014). In continuation of this work, we envisage that the synthesis of mixed Ibuprofen- Pyrimethamine metal complexes would lead to enhanced therapeutic ability on micro-organisms that have developed resistance to these drugs.

\section{MATERIALS AND METHODS}

All reagents and chemicals used for this research work were of analytical grade and utilized without further purification. Ibuprofen and Pyrimethamine were obtained from Rajrab Pharmaceutical company (Ilorin, Nigeria), while cadmium(II) chloride, zinc(II) chloride, cobalt(II) chloride, manganese(II) chloride were obtained from Sigma-Aldrich (USA). The melting point of the synthesized complexes was recorded on the Gallenkamp melting point apparatus (Melting point SMP 10) and conductivity measurements were carried out using Jenway 4510 conductivity meter at the Department of Chemistry, University of Ilorin, Ilorin, Nigeria. The IR spectra were recorded in $\mathrm{KBr}$ pellets within the range of 4000-400 cm-1 on the Buck Scientific M500 IR spectrometer at the Redeemer University, Sango-Ota, Nigeria. All organisms used for screening purposes of the complexes were obtained from the Department of Microbiology, University of Ilorin, Nigeria.

\subsection{Synthesis of the complexes}

The metal complexes were synthesized in line with the method adopted from Lawal and Obaleye (Lawal and Obaleye, 2007) with some modifications. $1 \mathrm{mmol}$ of $\mathrm{CdCl}_{2}, \mathrm{ZnCl}_{2}, \mathrm{CoCl}_{2}, \mathrm{MnCl}_{2}$, each dissolved in warmed aqueous solution ( $15 \mathrm{ml}$ ) was mixed to a cold solution of ibuprofen ( $1 \mathrm{mmol}, 15 \mathrm{ml}$ of ethanol) and solution of pyrimethamine ( $1 \mathrm{mmol}, 15 \mathrm{ml}$ of DMSO). The resulting mixture was stirred thoroughly and refluxed for 2 hours. It was left and allowed to stand for 24 hours. Immediately, the coloured precipitate was formed and isolated by filtration under vacuum. They were washed with mixed distilled water and ethanol and then dried in a desiccator using silica gel for further analysis.

\subsection{Antimicrobial Screening}

The antimicrobial screening was carried out by adopting the procedure reported by Ahmed et al. (2009) was adopted. The complexes were screened against the following selected organisms such as Gram-positive bacteria: Staphylococcus aureus, Bacillus substilis, Bacillus megaterium, and Gram-negative bacteria: 
Serratia marcescens, Escherichia coli, Pseudomonas aeruginosa. The complexes were dissolved in their suitable solvent at certain concentrations. Filter paper discs were used for screening by saturating the discs with the solution of the complexes. The filter paper discs were positioned on the surface of the prepared solidified nutrient agar plates. Afterwards, they were seeded by the organisms and then incubated for twenty-four hours at a temperature of $37^{\circ} \mathrm{C}$ for bacteria.

\subsection{Antimalarial activities}

The antimalarial study was investigated following the procedure. (Tella and Obaleye, 2010). Plasmodium berghei (NK 65 strain) was collected from Nigeria Institute of Medical Research and the parasites were maintained weekly by blood passage in mice.

\subsubsection{Inoculation of experimental mice}

The infection of the mice was performed within the cavity of the peritoneum with standard inoculum $(0.2$ $\mathrm{ml}$ of 1x10-7 parasitized Red blood cell). The inoculum was from a single donor mouse previously infected with Plasmodium berghei (33 percent parasitaemia).

\subsubsection{Animal grouping and extract administration}

After confirmation of parasitaemia in the animals, the animals were divided into six groups containing five mice, seventy-two hours post-inoculation. Test agents were orally given to the first four groups with different concentrations for five days while group 5 was given a standard drug for five days while group 6 (control) was left untreated but was administered an appropriate volume of distilled water (Adibi et al., 2012).

\subsubsection{Determination of percentage parasitaemia}

After twenty-eight days of investigation, the percentage of parasitaemia was evaluated using the formula below:

$$
\% \text { Parasitaemia }=\frac{\text { Parasitized RBC }}{\text { Parasitized RBC }+ \text { Non parasitized RBC }} \quad X 100
$$

\subsubsection{Determination of percentage chemosuppression}

The percentage chemosuppression was calculated using the formula:

$$
\% \text { Chemosuppression } A=\frac{\mathrm{B}-\mathrm{C}}{\mathrm{AC}}
$$

Where $\mathrm{B}=$ Parasitaemia in the study group, $\mathrm{C}=$ Parasitaemia in control

\subsection{Conductometry titration}

This type of conductometric titration was performed following the method reported by (Abdel-Nasser et al., 2009). The solution of ibuprofen $(0.01 \mathrm{M})$ was prepared in a 4:1 mixture of methanol and water. Metal ions were prepared using the same solvents with a concentration of $0.02 \mathrm{M}$. The Ibuprofen ligand was titrated against metal salts solution using a mono variation method and each conductance reading was taken after every $1 \mathrm{ml}$ of Ibuprofen was added. The graph of conductance against volume was plotted.

\subsection{Metal-chelation studies}

The procedure followed by (Renny et al., 2013) was adopted for the continuous variation and the determination of the composition of metal-chelation studies. Three series (C1, C2, C3) of an equimolar solution of ibuprofen ligands and metal salt solution were prepared.C1, 0-12 ml of metal salt was measured, and the total volume was made up to $12 \mathrm{ml}$ in each case. Also, in C2 ligand solution was measured and C3 metal salt was prepared by mixing of $0-12 \mathrm{ml}$ ligand solution. Conductance was taken and recorded for each solution and calculated using the $\mathrm{C} 1+\mathrm{C} 2-\mathrm{C} 3$ formula. 


\section{RESULTS AND DISCUSSION}

\subsection{Characterization of the compounds}

The analytical result of the metal complexes is presented as shown in Table 1. From the elemental analysis, the formation and stoichiometry of the complexes in ratio 1:1 was confirmed. The estimated metal contents of the complexes were observed and compared with the experimental data, as presented in Table 1 (AbdelNasser et al., 2009). It indicates that they are in good agreement with each other (Fig. 1). The complexes do not decompose in air. It was also observed that the melting point of the metal drug complexes was higher than their free ligands. This is due to the formation of coordination compounds; hence, the complexes are electrolyte in nature (Shaker et al., 2009).

\subsection{Infrared spectra analysis}

The IR spectra of the mixed complexes of Ibuprofen and Pyrimethamine are presented in Table 2. The broadband at $3300 \mathrm{~cm}-1$ in Ibuprofen was attributed to $v(\mathrm{OH})$ band. There was shifted to a higher frequency within the regions $3346-3399 \mathrm{~cm}-1$ in the complexes (Fig. 2). This is attributable to intra-hydrogen bonding interaction between the $\mathrm{H}$-atom of the hydroxyl group and its carbonyl group. The sharp band at $1720 \mathrm{~cm}$ 1 in Ibuprofen was assigned as $v(\mathrm{C}=\mathrm{O})$ stretching vibrations. This was shifted to a lower frequency between $1650-1696 \mathrm{~cm}_{-1}$ in all the complexes, an indication of the coordination of the oxygen of the carbonyl group in Ibuprofen (Ayad, 2002). The $v(\mathrm{~N}-\mathrm{H})$ frequency in the free Pyrimethamine was shifted in all the complexes. It was observed in the same region between $3306-3478 \mathrm{~cm}-1$ as in the free parent ligand. The $v(\mathrm{C}=\mathrm{O})$, which occurs at $1720 \mathrm{~cm}-1$ in Ibuprofen, is shifted to lower frequencies in all the complexes. It indicates that the central metal ions are directly coordinated to the oxygen of the carbonyl group (Shaker, 2009). The band at $519-647 \mathrm{~cm}-1$ was observed in all the complexes which are attributed to metal to nitrogen. Formation of new bands between $710-725 \mathrm{~cm}-1$ as assigned to $v(\mathrm{M}-\mathrm{O})$ and $v(\mathrm{M}-\mathrm{Cl})$ respectively. Pyrimethamine has four active coordinating sites. It was observed that Pyrimethamine and its complexes confirmed that the frequency bands which are attributed to the symmetrical and asymmetrical stretching mode of $\mathrm{NH}_{2}$, change the complexes. It signifies that coordination occurs through the nitrogen of the pyrimidine group. All the complexes were observed to be in octahedral geometry except $\mathrm{Zn}$ (II) complex (Bamigboye et al., 2015). All complexes were tested using the $\mathrm{AgNO}_{3}$ solution to determine the presence of chloride. A white precipitate of $\mathrm{AgCl}$ was formed and this showed the presence of chloride ion outside the co-ordination sphere (Aragoni et al., 2002).

\subsection{Antimalarial activity}

The complexes of mixed Pyrimethamine-Ibuprofen showed the antimalarial activity against the ligands based on the antimalaria activity, as shown in Table 3. Pyrimethamine was found to be effective than Ibuprofen. The average percentage for pyrimethamine is 31 . The ligands and the complexes were compared which indicated that the complexes are more effective than their parent ligands. It could be a result of the coordination of the ligands to the metal ions which improve the effectiveness of the drug. It could also be observed that $\mathrm{Co}$ (II) and $\mathrm{Zn}$ (II) complexes exhibited the same antimalaria activity at 70 percent (Tella and Obaleye, 2010). The parasitemia level was determined by the number of erythrocytes that are being infected with the organisms: Plasmodium berghei. Based on the result, it was observed that the parasitemia indicates a high presence of trophozoite; hence, complexes showed potent antimalarial activity (Osowole et al., 2015). Antimalarial activities of the complexes with respect to the percentage reduction in parasitaemia can be ranked as follows: $\left[\mathrm{Mn}(\mathrm{Pyr})(\mathrm{Ibu}) \mathrm{Cl}_{2}\right]>\left[\mathrm{Cd}(\mathrm{Pyr})(\mathrm{Ibu}) \mathrm{Cl}_{2}\right]>\left[\mathrm{Co}(\mathrm{Pyr})(\mathrm{Ibu}) \mathrm{Cl}_{2}\right]=\left[\mathrm{Zn}(\mathrm{Pyr})(\mathrm{Ibu}) \mathrm{Cl}_{2}\right]>$ [Ibuprofen] $>$ [Pyrimethamine]. Following the results obtained in this studies, percentage (\%) reduction in parasitemia for the synthesized compounds were more potent or active as compared to similar complexes reported by Tella and Obaleye (2010) with activities less than $70 \%$ as obtained in this study. 

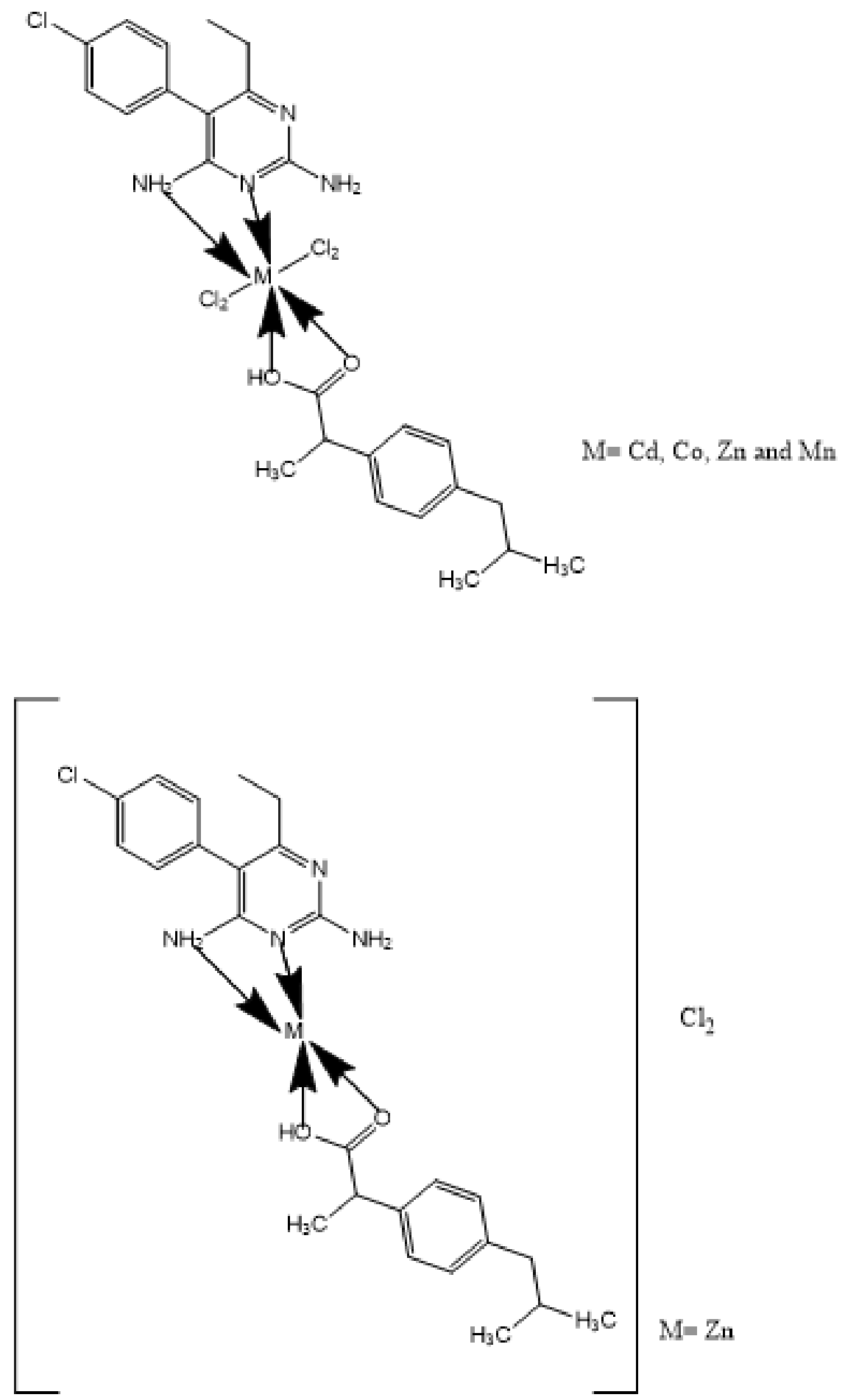

Figure 1. The proposed structure of the synthesized complexes. 


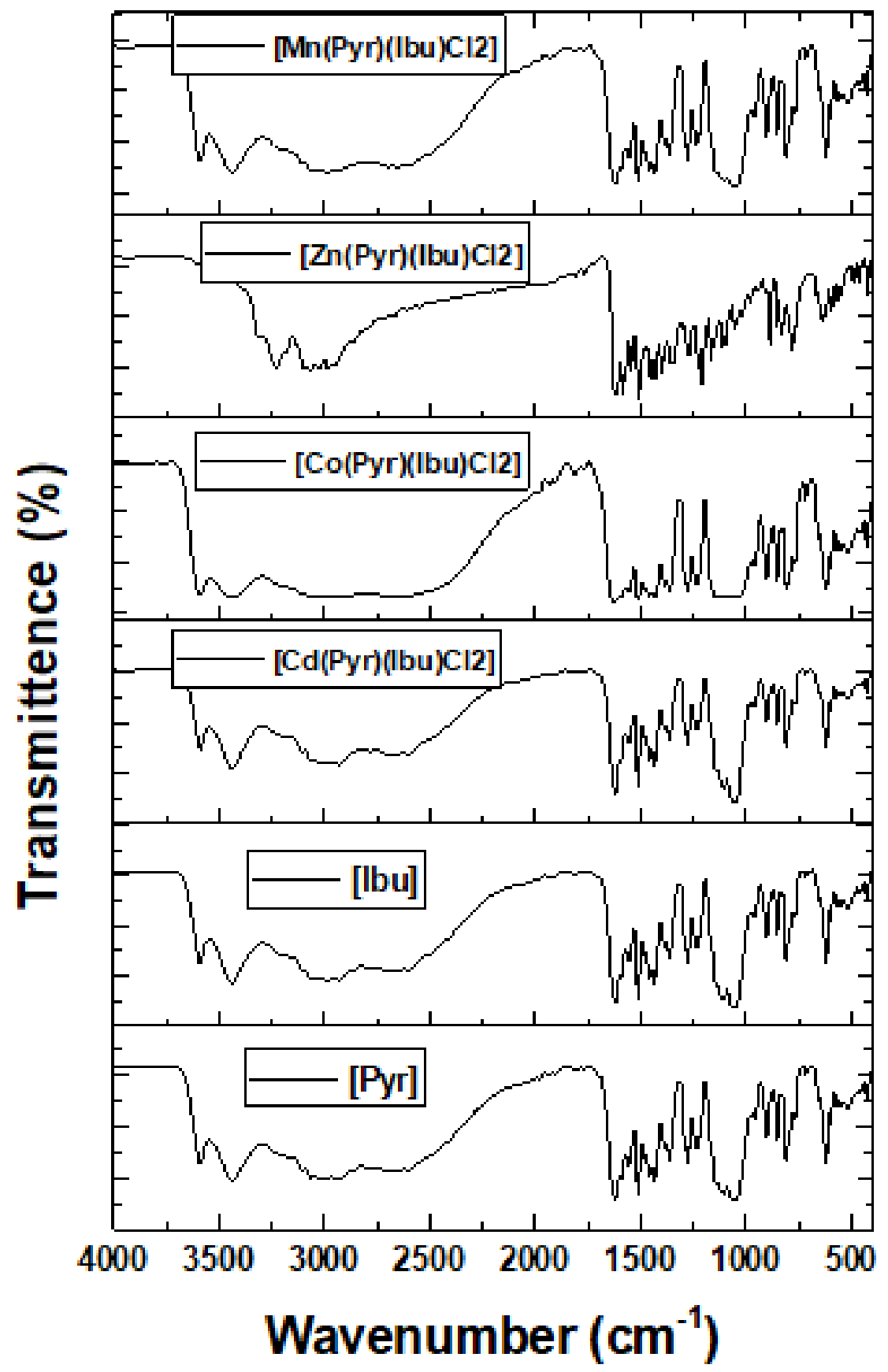

Figure 2. FT-IR of the ligands and the metal complexes.

Table 1. Analytical data of complexes.

\begin{tabular}{|c|c|c|c|c|c|c|}
\hline \multirow[t]{2}{*}{ Ligand/Complexes } & \multirow{2}{*}{$\begin{array}{l}\text { Melting } \\
\text { Point }\left({ }^{\circ} \mathrm{C}\right)\end{array}$} & \multirow{2}{*}{$\begin{array}{l}\text { Conductivity } \\
\Omega^{-1} \mathrm{~cm}^{2} \mathrm{~mol}^{-1}\end{array}$} & \multicolumn{3}{|c|}{ Elemental Analysis (Theo/ Exp) } & \multirow[b]{2}{*}{$\% \mathrm{O}$} \\
\hline & & & $\% \mathrm{C}$ & $\% \mathrm{H}$ & $\% \mathrm{~N}$ & \\
\hline Ibuprofen & 76 & - & - & - & - & - \\
\hline Pyrimethamine & 233 & - & - & - & - & - \\
\hline$\left[\mathrm{Cd}(\mathrm{Pyr})(\mathrm{Ibu}) \mathrm{Cl}_{2}\right]$ & 251 & 15 & $47.02 / 47.00$ & $4.86 / 4.82$ & $8.77 / 8.21$ & $5.02 / 5.21$ \\
\hline$\left[\mathrm{Co}(\mathrm{Pyr})(\mathrm{Ibu}) \mathrm{Cl}_{2}\right.$ & 249 & 17 & $51.30 / 51.45$ & $5.30 / 5.37$ & $9.58 / 9.52$ & $5.47 / 5.83$ \\
\hline$\left[\mathrm{Zn}(\mathrm{Pyr})(\mathrm{Ibu}) \mathrm{Cl}_{2}\right]$ & 255 & 12 & $50.74 / 50.65$ & $5.24 / 5.44$ & $9.47 / 9.00$ & $5.41 / 5.32$ \\
\hline$\left[\mathrm{Mn}(\mathrm{Pyr})(\mathrm{Ibu}) \mathrm{Cl}_{2}\right]$ & 243 & 14 & $51.65 / 50.99$ & $5.34 / 5.39$ & $9.64 / 9.21$ & $5.51 / 5.67$ \\
\hline
\end{tabular}


Table 2. Infrared data of the complexes.

\begin{tabular}{llllllll}
\hline Ligand/Complexes & $v(\mathrm{O}-\mathrm{H})$ & $v(\mathrm{C}=\mathrm{O})$ & $v(\mathrm{~N}-\mathrm{H})$ & $v(\mathrm{C}=\mathrm{N})$ & $v(\mathrm{M}-\mathrm{Cl})$ & $v(\mathrm{M}-\mathrm{N})$ & $v(\mathrm{M}-\mathrm{O})$ \\
\hline Ibuprofen & 3300 & 1720 & - & - & - & - & - \\
Pyrimethamine & - & - & 3450 & 1640 & - & - & - \\
{$\left[\mathrm{Cd}(\mathrm{Pyr})(\mathrm{Ibu}) \mathrm{Cl}_{2}\right]$} & 3399 & 1674 & 3478 & 1679 & 795 & 605 & 725 \\
{$\left[\mathrm{Co}(\mathrm{Pyr})(\mathrm{Ibu}) \mathrm{Cl}_{2}\right]$} & 3346 & 1650 & 3306 & 1698 & 754 & 519 & 710 \\
{$\left[\mathrm{Zn}(\mathrm{Pyr})(\mathrm{Ibu}) \mathrm{Cl}_{2}\right]$} & 3368 & 1672 & 3325 & 1672 & 791 & 625 & 713 \\
{$\left[\mathrm{Mn}(\mathrm{Pyr})(\mathrm{Ibu}) \mathrm{Cl}_{2}\right]$} & 3358 & 1696 & 3306 & 1653 & 799 & 647 & 718 \\
\hline
\end{tabular}

Table 3. Antimalarial activities of the complexes (Percentage reduction in parasitaemia).

\begin{tabular}{|c|c|c|c|}
\hline Ligand/Complexes & $\begin{array}{l}\text { \% Average } \\
\text { parasitaemia } \\
\text { before } \\
\text { administration }\end{array}$ & $\begin{array}{l}\text { \% Average } \\
\text { parasitaemia } \\
\text { after } \\
\text { administration }\end{array}$ & $\begin{array}{l}\% \text { reduction in } \\
\text { parasitaemia }\end{array}$ \\
\hline Pyrimethamine & 42 & 44 & 31 \\
\hline Ibuprofen & 40 & 58 & 45 \\
\hline$\left[\mathrm{Cd}(\mathrm{Pyr})(\mathrm{Ibu}) \mathrm{Cl}_{2}\right]$ & 85 & 90 & 77 \\
\hline$\left[\mathrm{Co}(\mathrm{Pyr})(\mathrm{Ibu}) \mathrm{Cl}_{2}\right]$ & 72 & 79 & 70 \\
\hline$\left[\mathrm{Zn}(\mathrm{Pyr})(\mathrm{Ibu}) \mathrm{Cl}_{2}\right]$ & 60 & 63 & 70 \\
\hline$\left[\mathrm{Mn}(\mathrm{Pyr})(\mathrm{Ibu}) \mathrm{Cl}_{2}\right]$ & 76 & 85 & 85 \\
\hline
\end{tabular}

\subsection{Conductometric Titration Study}

The plotted graph between corrected conductance against the volume of mole-metal ligand shows the equivalent point in the graph and it was concluded that complex formation had taken place in ratio 2:1 (Figs. 3 and 4). The conductance of the reaction mixture increased continuously with complexes under investigation and this could be attributed to the presence of the ligand in ionic form (Tables 4 and 5). From the results, the method of continuous variation of the complexes (Tables 6 and 7) the stoichiometry reaction for the formation of a metal ion complex between Pyrimethamine and Ibuprofen, it also determines the concentration of colored central metal ion complex in solution (Shivankar et al., 2012).

Table 4. Conductometric titration between Pyrimethamine and $\mathrm{CoCl}_{2}$.

\begin{tabular}{lll}
\hline Volume of metal ions & $\begin{array}{l}\text { Observed } \\
\text { conductance } \\
(\mathbf{m S})\end{array}$ & $\begin{array}{l}\text { Corrected } \\
\text { conductance } \\
(\mathbf{m S})\end{array}$ \\
\hline 0 & 0.098 & 0.990 \\
1 & 0.113 & 0.114 \\
2 & 0.125 & 0.123 \\
3 & 0.138 & 0.221 \\
4 & 0.216 & 0.265 \\
5 & 0.260 & 0.315 \\
6 & 0.314 & 0.319 \\
7 & 0.317 & 0.320 \\
8 & 0.319 & 0.440 \\
9 & 0.436 & 0.503 \\
10 & 0.492 & 0.500 \\
\hline
\end{tabular}


Table 5. Conductometric titration between Ibuprofen and $\mathrm{CoCl}_{2}$.

\begin{tabular}{lll}
\hline Volume of metal ions & $\begin{array}{l}\text { Observed } \\
\text { conductance } \\
(\mathbf{m S})\end{array}$ & $\begin{array}{l}\text { Corrected } \\
\text { conductance } \\
(\mathbf{m S})\end{array}$ \\
\hline 0 & 0.019 & 0.019 \\
1 & 0.148 & 0.150 \\
2 & 0.204 & 0.218 \\
3 & 0.213 & 0.219 \\
4 & 0.309 & 0.311 \\
5 & 0.346 & 0.350 \\
6 & 0.415 & 0.418 \\
7 & 0.436 & 0.436 \\
8 & 0.518 & 0.519 \\
9 & 0.523 & 0.528 \\
10 & 0.492 & 0.500 \\
\hline
\end{tabular}

Table 6. Job's method (Concentration of Pyrimethamine $0.01 \mathrm{M}$ and concentration of $\mathrm{CoCl}_{2} 0.01 \mathrm{M}$ ).

\begin{tabular}{lllll}
\hline Ratio & & \multicolumn{2}{l}{ Conductance $(\mathbf{m S})$} \\
\cline { 3 - 5 } & $\mathbf{M : S ( C 2 )}$ & $\mathbf{M : L}(\mathbf{C} 3)$ & $\boldsymbol{\Delta}(\mathbf{C} 1+\mathbf{C} 2-\mathbf{C} 3)$ \\
\hline $0: 10$ & 0.008 & 0.013 & 0.012 & 0.009 \\
$1: 9$ & 0.012 & 0.014 & 0.016 & 0.010 \\
$2: 8$ & 0.025 & 0.019 & 0.021 & 0.023 \\
$3: 7$ & 0.037 & 0.024 & 0.025 & 0.036 \\
$4: 6$ & 0.041 & 0.030 & 0.034 & 0.037 \\
$5: 5$ & 0.038 & 0.032 & 0.040 & 0.030 \\
$6: 4$ & 0.029 & 0.028 & 0.035 & 0.022 \\
$7: 3$ & 0.025 & 0.025 & 0.026 & 0.024 \\
$8: 2$ & 0.022 & 0.018 & 0.016 & 0.042 \\
$9: 1$ & 0.011 & 0.015 & 0.014 & 0.012 \\
$10: 0$ & 0.010 & 0.012 & 0.011 & 0.011 \\
\hline
\end{tabular}

Table 7. Job's method (Concentration of Ibuprofen $0.01 \mathrm{M}$ and concentration of $\mathrm{CoCl}_{2} 0.01 \mathrm{M}$ ).

\begin{tabular}{lllll}
\hline Ratio & & \multicolumn{2}{l}{ Conductance $(\mathbf{m S})$} \\
& M:S(C1) & S:L(C2) & M:L(C3) & $\boldsymbol{\Delta}(\mathbf{C} 1+\mathbf{C} 2-\mathbf{C 3})$ \\
\hline $0: 10$ & 0.010 & 0.013 & 0.014 & 0.009 \\
$1: 9$ & 0.015 & 0.016 & 0.020 & 0.011 \\
$2: 8$ & 0.020 & 0.021 & 0.028 & 0.013 \\
$3: 7$ & 0.031 & 0.026 & 0.034 & 0.023 \\
$4: 6$ & 0.038 & 0.031 & 0.036 & 0.033 \\
$5: 5$ & 0.043 & 0.040 & 0.043 & 0.040 \\
$6: 4$ & 0.035 & 0.035 & 0.038 & 0.032 \\
$7: 3$ & 0.032 & 0.030 & 0.035 & 0.027 \\
$8: 2$ & 0.023 & 0.021 & 0.033 & 0.011 \\
$9: 1$ & 0.018 & 0.020 & 0.030 & 0.008 \\
$10: 0$ & 0.015 & 0.017 & 0.026 & 0.006 \\
\hline
\end{tabular}




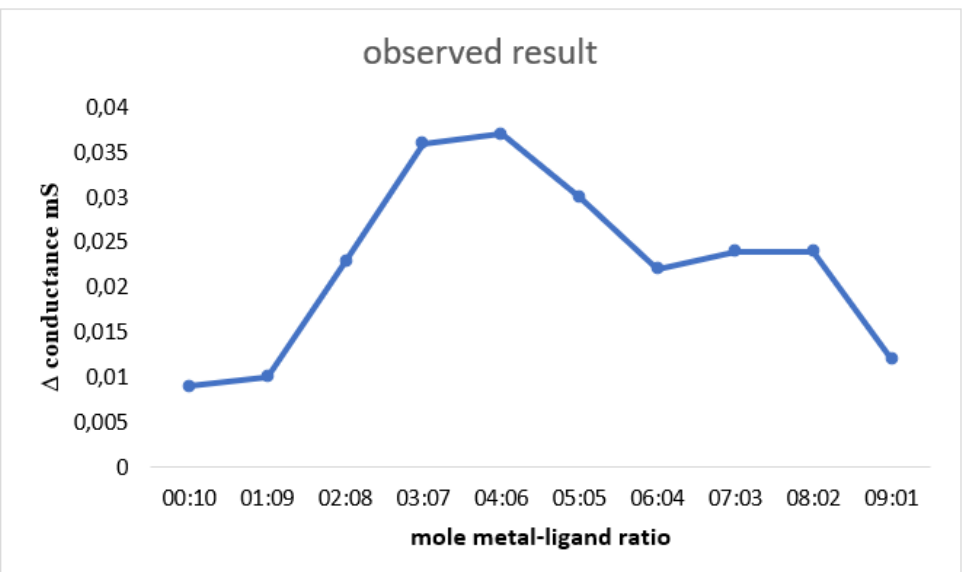

Figure 3. Graph of Job's method (Concentration of Pyrimethamine $0.01 \mathrm{M}$ and concentration of $\mathrm{CoCl}_{2}$ $0.01 \mathrm{M})$.

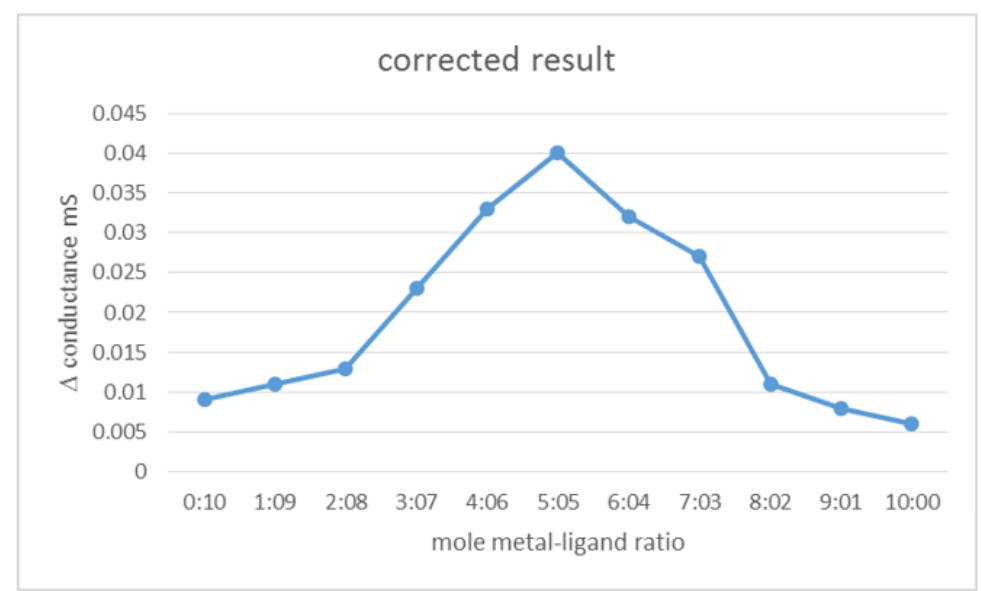

Figure 4. Graph of Job's method (Concentration of Ibuprofen $0.01 \mathrm{M}$ and concentration of $\mathrm{CoCl}_{2} 0.01 \mathrm{M}$ ).

Table 8. Antimicrobial activities of the complexes.

\begin{tabular}{lllllll}
\hline Ligands/Complexes & & \multicolumn{5}{c}{ Zone of Inhibition (mm) } \\
& Sm(-ve) & Bs(+ve) & Ec(-ve) & Sa(+ve) & Pa(-ve) & Bm(+ve) \\
\hline Pyrimethamine & - & - & 9 & - & 11 & 13 \\
Ibuprofen & 2 & - & 5 & - & 2 & 4 \\
{$\left[\mathrm{Cd}(\mathrm{Pyr})(\mathrm{Ibu}) \mathrm{Cl}_{2}\right]$} & 14 & 25 & 29 & 15 & 19 & 27 \\
{$\left[\mathrm{Co}(\mathrm{Pyr})(\mathrm{Ibu}) \mathrm{Cl}_{2}\right]$} & 21 & 32 & 21 & 45 & 23 & 31 \\
{$\left[\mathrm{Zn}(\mathrm{Pyr})(\mathrm{Ibu}) \mathrm{Cl}_{2}\right]$} & 33 & 28 & 14 & 24 & 17 & 20 \\
{$\left[\mathrm{Mn}(\mathrm{Pyr})(\mathrm{Ibu}) \mathrm{Cl}_{2}\right]$} & 16 & 22 & 18 & 15 & 20 & 26 \\
\hline
\end{tabular}

Footnote: $\mathrm{Sm}(-\mathrm{ve})=$ Serratia marcescens, $\mathrm{Bs}(+\mathrm{ve})=$ Bacillus substilis, $\mathrm{Ec}(-\mathrm{ve})=$ Escherichia coli, $\mathrm{Sa}(+\mathrm{ve})=$ Staphylococcus aureus, $\mathrm{Pa}(-\mathrm{ve})=$ Pseudomonas aeruginosa, $\mathrm{Bm}(+\mathrm{ve})=$ Bacillus megaterium.

\subsection{Antimicrobial activity}

Careful observation of the results obtained on antimicrobial activities of the ligands and complexes, it is evident that the complexes indicate higher activities against the studied organisms as compared with the free ligands at $20 \mu \mathrm{g} / \mathrm{ml}$ (Table 8). Antimicrobial resistance against some antimalarial and antibiotic drugs 
are common in most countries. Several studies have reported that coordination enhances the effectiveness of metal complexes, thereby acting as potent bacterial agents (Srinivasan et al., 2003). Mixed-ligand complex $\left[\mathrm{Co}(\mathrm{Pyr})(\mathrm{Ibu}) \mathrm{Cl}_{2}\right]$ exhibited antimicrobial activities against both $S$. marcescens and $E$. coli bacteria tested with inhibition zone valve of $21 \mathrm{~mm}$, and highest inhibition against $S$. aureus with zone value of 45 $\mathrm{mm}$ (Table 8; Fig. 5). Antimicrobial activities of the compounds against $P$. aeruginosa (gram -ve) is in the order: $\left[\mathrm{Co}(\mathrm{Pyr})(\mathrm{Ibu}) \mathrm{Cl}_{2}\right]>\left[\mathrm{Mn}(\mathrm{Pyr})(\mathrm{Ibu}) \mathrm{Cl}_{2}\right]>\left[\mathrm{Cd}(\mathrm{Pyr})(\mathrm{Ibu}) \mathrm{Cl}_{2}\right]>\left[\mathrm{Zn}(\mathrm{Pyr})(\mathrm{Ibu}) \mathrm{Cl}_{2}\right]>[\mathrm{Pyrimethamine}]$ $>$ [Ibuprofen], while the compounds activities against B. megaterium (gram +ve) can be ranked as follows: $\left[\mathrm{Co}(\mathrm{Pyr})(\mathrm{Ibu}) \mathrm{Cl}_{2}\right]>\left[\mathrm{Cd}(\mathrm{Pyr})(\mathrm{Ibu}) \mathrm{Cl}_{2}\right]>\left[\mathrm{Mn}(\mathrm{Pyr})(\mathrm{Ibu}) \mathrm{Cl}_{2}\right]>\left[\mathrm{Zn}(\mathrm{Pyr})(\mathrm{Ibu}) \mathrm{Cl}_{2}\right]>[\mathrm{Pyrimethamine}]>$ [Ibuprofen]. However, due to aromaticity within the ligands, the coordination significantly increases the antimicrobial activity of the complexes. It has been discovered and reported that the ligands with nitrogen and oxygen donor active sites can inhibit enzyme production (Ejidike, 2018). The enzymes need these groups for their activity to be more susceptible to deactivation by the central metal ions upon coordination. It has been reported that coordination helps to lower the metal ion polarity also known as Tweedy chelation theory (Ejidike, 2018; Mosiniewicz-Szablewska et al., 2003) of the central metal ions due to donating of its positive charge through the donor atoms. The reaction of coordination helps to increases the lipophilic character of the metal ions which help its permeation through the lipid layer of the membrane. This increase in the hydrophobic behaviour and liposolubility of the complexes bring about crossing in the cell membrane of the organism leading to cell respiratory activity disruption and restricts further organism growth (Ejidike and Ajibade, 2017).

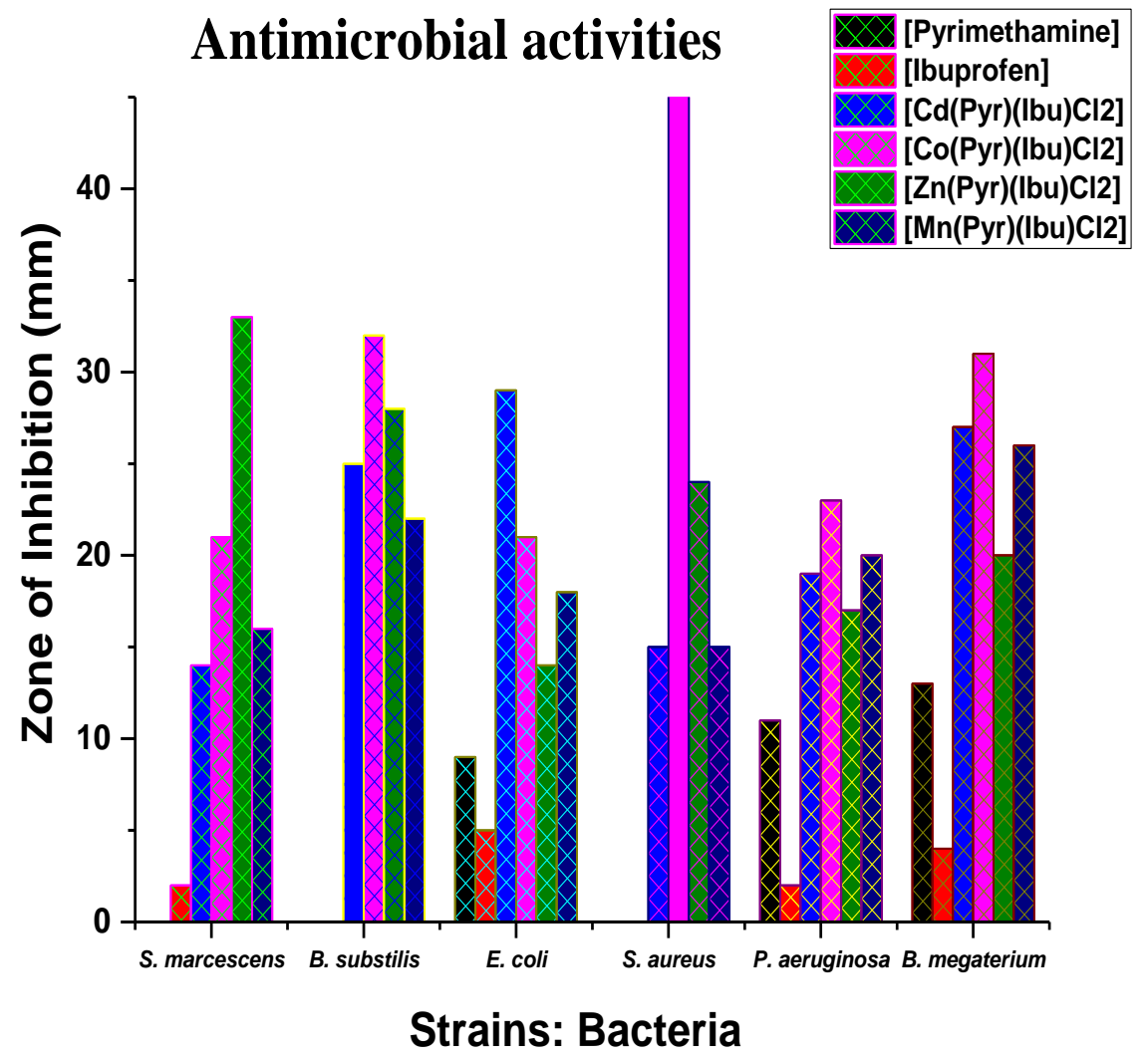

Figure 5. Zone of Inhibition of the compounds against studied bacteria strains. 


\section{CONCLUSION}

$\mathrm{Cd}(\mathrm{II}), \mathrm{Co}$ (II), $\mathrm{Zn}$ (II), and $\mathrm{Mn}$ (II) complexes of mixed Pyrimethamine and Ibuprofen has been synthesized and characterized. Based on the results obtained, octahedral geometry has been proposed for the complexes except for $\mathrm{Zn}$ (II) complex which is in a tetrahedral geometry. Antimalarial and antimicrobial activities of mixed ibuprofen-pyrimethamine $\mathrm{M}$ (II) complexes $[\mathrm{M}=\mathrm{Cd}, \mathrm{Co}, \mathrm{Zn}, \mathrm{Mn}]$ indicated that the complexes exhibited higher activity as compared to the parent ligands. The multi-potential activities of the synthesized compounds support its usage for the development of chemotherapeutic agents useful for microbiological related ailments treatment.

\section{Acknowledgments}

The authors acknowledged that no financial support was received from any research organization in support of this work.

\section{REFERENCES}

Abdel-Nasser, M.A., Alaghaz, R.A., Ammar Hany, M. (2009). Studies on the chelation of cyclodiphosph (V) azane complexes of $\mathrm{Co}(\mathrm{II})$, $\mathrm{Ni}(\mathrm{II}), \mathrm{Cu}(\mathrm{II}), \quad$ and $\mathrm{Pd}(\mathrm{II})$ : Preparation, characterization, thermal, solid-state electrical conductivity, and biological activity studies. J. Phosphorus, Sulfur, and Silicon and the Related Elements. 184(9), 2472-2490.

Adibi, H., Zaker, S., Monkaresi, H. (2012). Synthesis and characterization of hydrazidehydrazone derivatives of 3-pyridine carboxylic acid as antimycobacterial tuberculosis agents. J. Rep. Pharma. Sci. 1(1), 60-66.

Ahmed, R.N., Sani, A., Igunnugbemi, O.O. (2009). Antifungal profiles of extracts of Vitellaria paradoxa (shea-butter) bark. Ethnobot. Leaflets 13, 679-688.

Alaghaz, A.N.M.A., Farag, R.S., Elnawawy, M.A., Ekawy, A.D.A. (2013). Synthesis and spectral characterization studies of new trimethoprimdiphenylphosphate metal complexes. Int. Jour. Sci. Res. 5(1), 1220-1229.

Aragoni, M.C., Arca, M., Demartin, F. (2002). Fluorometric chemosensors. Interaction of toxic heavy metal ions $\mathrm{Pb}(\mathrm{II}), \mathrm{Cd}(\mathrm{II})$, and $\mathrm{Hg}(\mathrm{II})$ with novel mixed-donor phenanthroline-containing macrocycles: spectrofluorometric, conductometric, and crystallographic studies," Inorg. Chem. 41(1): 6623-6632.
Ayad, M.M. (2002). Spectrophotometric and AAS determination of ramipril and enalapril through ternary complex formation. J. Pharm. Biomed. Anal. 28(1), 311-321.

Babamale, H.F., Lawal, A., Rajee, O.A., Oloyede, E.A. (2006). Synthesis, characterization and biological activity studies of mixed paracetamol ascorbic acid metal complexes. J. Appl. Sci. Environ. Manage. 20(4), 1157-1161.

Bamigboye, M.O., Tella, A.C., Gbadebo, T.E., Eke, U.B., Obaleye, J.A. (2015). AmodiaquineIbuprofen mixed metal complexes: synthesis, characterization and antimicrobial activities. Centrepoint Journal (Science Edition). 21(2), 8493.

Cassells, I., Stringer, T., Smith, G.S. (2018). Impact of various lipophilic substituents on ruthenium(II), rhodium(III) and iridium(III) salicylaldimine-based complexes: synthesis, in vitro cytotoxicity studies and DNA interactions. J. Bio. Inorg. Chem. 23(5), 763-774.

Ejidike, I.P. (2018). Cu(II) Complexes of 4-[(1E)$N$-\{2-[(Z)-Benzylidene-amino]ethyl $\}$ ethanimidoyl] benzene-1,3-diol Schiff base: Synthesis, spectroscopic, in-vitro antioxidant, antifungal and antibacterial studies. Mol. 23(7), 1581.

Ejidike, I.P., Ajibade, P.A. (2017). Synthesis, spectroscopic, antibacterial and free radical 
scavenging studies of $\mathrm{Cu}(\mathrm{II}), \mathrm{Ni}(\mathrm{II}), \mathrm{Zn}$ (II) and Co(II) complexes of 4,4'-\{ethane-1,2diylbis[nitrilo(1E)eth-1-yl-1-ylidene] \} dibenzene1,3-diol Schiff base. J. Pharm. Sci. Res. 9(5), 593600.

Enermose, E.A., Akporhnonor, E.E., Osakwe, S.A. (2014). $\mathrm{Cu}(11)$ and $\mathrm{Ni}(\mathrm{II})$ complexes of sulphamethazine mixed with pyrimethamine: synthesis, characterization and antimicrobial study. Chem. Mat. Res. 6(6), 9-14.

Huang, T.H., Yan, J., Yang, H., Tan, C., Yang, Y. (2016). Synthesis, structures, and properties of polynuclear silver complexes containing tetraphosphine ligand with $\mathrm{Ag} \cdot \mathrm{C}$ interactions. Austr. J. Chem. 69(3), 336-342.

Ibrahim, N.M., Yosef, H.A.A., Ewies, E.F., Mahran, M.R.H., Ali, M.M., Mahmoud, A.E. (2015). Synthesis and antitumor evaluation of new heterocycles derived from 3-Methyl-2benzothiazolinone hydrazone. J. Braz. Chem. Soc. 26(6), 1086-1097.

Lawal, A., Obaleye, J.A. (2007). Synthesis, characterization and antibacterial activity of aspirin and paracetamol metal complexes. Nigerian Society for experimental biology. Biokemistri. 19(1), 9-15.

Li-June, M. (2003). Structure and function of metallo-antibiotics. Med. Res. Rev. 23(6), 697-762.

Mosiniewicz-Szablewska, E., Slawska-Waniewska, A., Swiatek, K., Nedelko, N., Golebiewski, N. (2003). Magnetic properties of Ni-complexes in a hydrazone structure. Phy. Stat. Solid. (A) Appl. Res. 196(1), 213-216.

Osowole, A.A., Wakil, S.M., Alao, O.K. (2015). Synthesis, characterization and antimicrobial activity of some mixed trimethoprimsulfamethoxazole metal complexes. World Appl. Sci. J. 33(2), 336-342.

Padman, S., Sapna, T., Sing, A.P. (2016). Synthesis, spectral characterization and antimicrobial studies of Schiff bases and their mixed ligand metal complexes of $\mathrm{Co}(\mathrm{II}), \mathrm{Ni}(\mathrm{II}), \mathrm{Cu}(\mathrm{II})$ and $\mathrm{Zn}$ (II). Am. J. Chem. 6(5), 119-125.

Mahdi, R.T., Al-Noor, T.H., Ismail, A.H. (2014). Preparation, characterization, and antibacterial properties of mixed ligand complexes of L-leucine and Sulfamethoxazole with $\mathrm{Mn}(\mathrm{II}), \mathrm{Co}(\mathrm{II}), \mathrm{Ni}(\mathrm{II})$, $\mathrm{Cu}(\mathrm{II}), \mathrm{Zn}(\mathrm{II}), \mathrm{Cd}(\mathrm{II})$ and $\mathrm{Hg}(\mathrm{II})$ ions. Advances in Physics Theories and Applications 27(1), 8-19.

Ramachandran, R., Prakash, G., Vijayan, P., Viswanathamurthi, P., Malecki, J.G. (2017). Synthesis of heteroleptic copper(I) complexes with phosphine-functionalized thiosemicarbazones: an efficient catalyst for regioselective $\mathrm{N}$-alkylation reactions. Inorganica Chim. Acta. 464(5), 88-93.

Recio Despaigne, A.A., Da Silva, J.G., da Costa, P.R., Dos Santos, R.G., Beraldo, H. (2014). ROSmediated cytotoxic effect of copper(II) hydrazone complexes against human glioma cells. Molecules 19, 17202-17220.

Renny, J.S., Tomasevich, L.L., Tallmadge, E.H., Collum, D.B. (2013). Method of continuous variations: Applications of job plots to the study of molecular associations in organometallic chemistry. Angew. Chem. Int. Ed. Engl. 52(46), 11998-12013.

Naveed, S., Jaweed., L. (2014). UV spectrophotometric assay of different brands of cephradine. Health Sciences Research 1(4), 84-87.

Shaker, S.A., Farina, Y. (2009). Preparing and characterization of some mixed ligands complexes of 1,3,7-trimethylxanthin, y-picoline and thiocyanate with some metal ions. Am. J. Sci. Res. 5, 20-26.

Shaker, S.A., Farina, Y., Mahmmod, S., Eskendar M. (2009). Preparation and study of mixed ligand complexes of caffeine and cyanate with some metal ions. Aust. J. Basic Appl. Sci. 3(4), 3337-3340.

Shivankar, V.S., Burungale, A.S., Rajmane, M.M., Gavali, L.V. (2012). Synthesis, characterization and catalytic activity of mixed ligand transition metal complexes. Arch. Appl. Sci. Res. 4(5), 2289-2298. 
Srinivasan, R., Sougandi, I., Venkatesan, R., Sambasiva Rao, P. (2003). Synthesis and room temperature single crystal EPR studies of a dinickel complex having an $\mathrm{Ni}(\mu$-phenoxide)22+ unit supported by a macrocyclic ligand environment $\left[\mathrm{Ni} 2(\mathrm{~L})_{2}\left(\mathrm{OClO}_{3}\right)_{2}\right] \quad[\mathrm{L}=2$-[(4-methyl-pyridin-2ylimino)-methyl]-phenol]. Proceedings of the Indian Academy of Sci. 115(2), 91-102.

Tella, A.C., Obaleye, J.A. (2010). Synthesis and biological studies of $\mathrm{Co}(\mathrm{II})$ and $\mathrm{Cd}(\mathrm{II})$ 5-(3,4,5trimethoxybenzyl)pyrimidine-2,4-diamine
(Trimethoprim) complexes. Int. J. Biol. Chem. Sci. 4(1), 2181-2191.

Triathi, I.P., Aarti, K. (2015). Synthesis and characterization of some complexes of copper(II) with L-Asparginine, L-Histidine, L-Lysine. Am. J. Alzh. Dis. Dem. 3(1), 95-103.

Waziri, M.B., Fugu, N.P. (2018). Solvent-free synthesis, characterization and antimicrobial studies of calcium and potassium complexes with some cephalosporin antibiotics. Res. J. Chem. Sci. 8(6), 8-15. 